\title{
China-Pakistan Economic Cooperation: The Case of Special Economic Zones (SEZs)
}

\author{
Ejaz Hussain ${ }^{1}$ (D) Muhammad Furqan Rao $^{2}$ \\ Received: 14 November 2019 / Accepted: 8 August 2020 / Published online: 28 August 2020 \\ (c) Fudan University 2020
}

\begin{abstract}
This article attempts to underscore the extraordinary significance of Special Economic Zones (SEZs) in the industrialization and economic growth of Pakistan as well as the development and consolidation of China-Pakistan Economic Corridor (CPEC)—which is a core component of the Belt and Road Initiative (BRI). Though Pakistan has previously experimented with SEZs, its scale, outreach and impact on the country's economy and society remained very limited. Thus, the proposed SEZs under the CPEC offer new opportunities for mutual economic cooperation, investment, human resource development, sustained industrialization and, above all, the consolidation of CPEC. Nevertheless, there are several challenges ranging from structural issues to security problems that the proposed SEZs, in particular, and CPEC, in general, face. The article, thus, provides a comprehensive set of strategies to convert challenges into capabilities.
\end{abstract}

Keywords CPEC $\cdot$ SEZs $\cdot$ BRI $\cdot$ China $\cdot$ Pakistan

\section{Introduction}

Pakistan experienced slow growth rate ranging from $0.4 \%$ in $2008-2009$ to $4.24 \%$ in 2014-2015. ${ }^{1}$ Nevertheless, owing to certain strategic and economic developments that include the construction of China-Pakistan Economic Corridor (CPEC), the country's economy reflected positive trends in all major sectors of the economy

\footnotetext{
1 "Highlights of Pakistan Economic Survey 2014-2015," Finance Division, Government of Pakistan, Islamabad, 2015. http://www.finance.gov.pk/survey/chapters_15/Highlights.pdf (accessed on 14 July 2020).
}

Ejaz Hussain

ejaz.hussain@iqraisb.edu.pk

1 Department of Social Sciences, Iqra University, Plot No. 5, H-9, Islamabad, Pakistan

2 Tsinghua University, Beijing, China 
during 2014-2018. Therefore, the GDP growth rate stood at 5.2\% (revised) in $2018 .^{2}$ Though the global donors and ratings institutions are pinning hope on the country's economic potential to rise as a fast-growing and promising regional economy, Pakistan, due to prevailing structural constrains, is still struggling with its stated economic goals that include around $8 \%$ annual growth rate. ${ }^{3}$ In addition, during the first quarter of fiscal year 2018-2019, the GDP growth rate has dropped from 5.2 percent to 3.8 percent. $^{4}$ Importantly, owing to Covid-19, the country's GDP growth rate for 2020-2021 has been projected negatively. ${ }^{5}$

In the wake of sustained economic growth regionally if not globally, it is pertinent for Pakistan to revisit its economic policy for the country possesses certain infrastructural, demographic and human resource potential that can play a pivotal role in shaping the socioeconomic profile of the country in an unprecedented manner. For instance, during the past four decades, Pakistan's manufacturing sector registered an average annual rate of around $7 \%$ despite a slowdown in recent years. This marks resilience of the Pakistani industries and entrepreneurs, which is very crucial for sustained economic growth. ${ }^{6}$

In order to achieve the stated annual growth rate, realize full potential of its natural and human resources, improve upon its agriculture and manufacturing sector and, overall, rise as a stable regional economy, Pakistan has already taken certain concrete measures. In this respect, the launch in 2015, of the landmark project of coordination and cooperation between China and Pakistan, namely the China-Pakistan Economic Corridor (CPEC), has emerged as an icon for fast-tracked industrial development and dissemination. Thus, in the context of CPEC, Pakistan aims to establish financially vibrant, socially visible and potentially productive industries to initiate a new era of industrialization that includes high-end textiles, telecom, engineering, knowledge-based manufacturing, sea products and sophisticated storage facilities for fruits and vegetables, jointly or separately with Chinese companies to be based in Special Economic Zones (SEZs). "While embarking on the [new] phase of industrialization, Pakistan faces a number of issues that have so far restricted industries to realize their growth potential. These include, low investment, dispersal of industries across country, weak institutions, low quality human resources, shallow tooling skills owing to lack of depth in vocational expertise, lack of modern technology, high business cost, brain-drain, low quality hard and soft infrastructure, etc." argued Mahmood. ${ }^{7}$

\footnotetext{
${ }^{2}$ Reuters, "Pakistan central bank sees 2019 GDP growth slowing to 3.5-4.0 percent,". March 25, 2019. https://in.reuters.com/article/pakistan-economy/pakistan-central-bank-sees-2019-gdp-growth-slowing-to35-40-percent-idINKCN1R61JE (accessed on 14 April 2019).

3 Government of Pakistan, Pakistan Economic Survey, 2016-17 (Islamabad: Ministry of Finance, 2016). http://www.finance.gov.pk/survey_1617.html (accessed on 13 January 2018).

4 Reuters, "Pakistan central bank sees 2019 GDP growth slowing to 3.5204 .0 percent,".

5 Mehtab Haider, "World Bank predicts Pakistan GDP growth at -0.2pc next fiscal," The News, 10 June 2020. https://www.thenews.com.pk/print/670543-world-bank-predicts-pakistan-dgp-growth-at-0-2pcnext-fiscal (accessed on 15 July 2020).

6 Ibid.

7 Zafar Mahmood, "Opportunities and Challenges of Sino-Pak Industrial Cooperation and Industrial Zones Construction" (paper presented at the International Academic Seminar on Industrial Cooperation and Construction of Industrial Zones, CPEC, Peking University, Beijing, 2018).
} 
Expectedly, the SEZs under CPEC offer lifetime opportunity for Pakistani companies to work in tandem with their Chinese counterparts for the development of export-oriented manufacturing industries, while striving to overcome the abovementioned issues with the assistance of reformed public sector institutions. The SEZs with new business models are likely to generate reasonable jobs, develop industrial and business infrastructures and establish domestic value chains connected regionally and extra-regionally. Thus, the Special Economic Zones are expected to provide much needed impetus to stimulate economic activities across the country. ${ }^{8}$

Moreover, given the relatively successful record of China in constructing and running several SEZs, Pakistan finds an opportunity to capitalize on the Chinese experiences and, importantly, investment, human resources and technology in establishing China-led industrial parks. In this new phase of industrialization under the framework of China-Pakistan Economic Corridor, Pakistan is expected to have a number of opportunities to capitalize on. Nevertheless, the country's leadership, both civil and the military, would also face multiple challenges at the policy and operational level. In order to turn CPEC into a success story for bilateral economic confidence and, overall, for the positive projection of the Belt and Road Initiative (BRI), the construction of Special Economic Zones, thus, assumes extraordinary significance.

In view of the foregoing, this article, therefore, is an attempt to underscore the overwhelming significance of Special Economic Zones for the expansion and consolidation of China-Pakistan Economic Corridor-which is a core component of the Belt and Road Initiative. In doing so, the article attempts to address the following questions: Did Pakistan ever venture in SEZs pre-CPEC? What are the nature, character, geographic scale and socioeconomic outreach of the proposed SEZs under CPEC? What type of challenges the proposed SEZs, especially the Rashakai Special Economic Zone-which is prioritized in terms of construction by the two governments on April 29, 2019-face? Are there any solutions to the identified set of challenges? This article, in the following sections, addresses these questions empirically. In this respect, qualitative method is employed, while data include both primary and secondary sources. ${ }^{9}$ Nonetheless, before so doing, it is prudent to review the major works on SEZs in order to draw cross-regional insights that would be useful for the identification of challenges and the formulation and implementation of strategies.

\section{Literature Review}

Human beings, since antiquity, are instinctively inclined toward socialization which gradually generated a sense of commodity exchange. The structural transformation from the Paleolithic period to the Neolithic era marked the differentiated primacy of agrarian relations cross-regionally. ${ }^{10}$ The early civilizations enriched human

\footnotetext{
8 Ibid.

9 Paul,Pennings, Hans Keman and Jan Kleinnijenhuis, Doing Research in Political Science: An Introduction to Comparative Methods and Statistics, 2nd edn. (London: Sage, 2006).

10 Rondo Cameron, A Concise Economic History of the World: From Paleolithic Times to the Present (New York: Oxford University Press, 1993), 20-43.
} 
organization culturally, artistically and intellectually. The advent of "common era" witnessed the feudalization of, for instance, the European society where the means of production-essentially agrarian in nature and character-were controlled by the higher echelon of the empire-state. In the middle medieval to the late medieval period in world economic history, the contribution of the non-Western world was remarkable in terms of proto-trade of, for example, silk, gunpowder and paper technology from China. $^{11}$

Thus, the antecedents of modern "industrialization" could be observed in the sustained exchange relations among the Ottoman empire, the Qing dynasty and various European dynasties. While the Asian empire-states could not pursue industrialization on account of strategic and political calculations, the Europeans, especially the British, took lead in setting up a variety of industrial units across the country in the thirteenth century onwards. ${ }^{12}$ Such institutional changes, thus, brought forth structural transformation of the market relations from feudalism to capitalism. Moreover, it also had a bearing on the nature of political relations that, on account of the European revolutions, i.e., 1688, culminated into the formation of the nation-state postFrench revolution. Ironically, however, the modern nation-states of Europe and later North America adopted a contradictory approach by extracting raw material from the non-Western world in order to sustain industrialization at home. This process of structural exploitation ultimately resulted into colonialism of the Asian and African societies and markets from the nineteenth to the mid-twentieth century. ${ }^{13}$

Nonetheless, the capitalist colonial hegemony was challenged by mostly socialist forces during the First World War, i.e., the Russian Revolution (1917), onwards till the final phase of decolonization in the 1960s. ${ }^{14}$ In the post-Second World War period, the United States emerged as the leader of the capitalist bloc, whereas the USSR and the People's Republic of China, as it emerged as a sovereign nation-state in 1949, represented the socialist model of governance and economy. It is in this context of the Cold War geoeconomics that the Western world, in order to expand its industrial production, invested innovatively in finding new means for enhancing its manufacturing sector and broadening the export base. The British, again, took lead, in this respect, by establishing the first modern export processing zone (EPZ) in Ireland in 1959. ${ }^{15}$ The following decade witnessed the establishment of EPZs in Barcelona (Spain) and Puerto Rico (USA). In Asia, India became the first country to conceptualize EPZ and, consequently, established its first EPZ in Kandla (Gujarat) in $1965 .^{16}$

\footnotetext{
${ }^{11}$ R. J. Holton, The Transition from Feudalism to Capitalism (New York: St. Martin's Press, 1985), $11-28$.

${ }^{12}$ Acemoglu Daron and James A. Robinson, Why Nations Fail? The Origins of Power, Prosperity, and Poverty. (London: Profile Books Limited, 2012), 182-212.

13 Daron and Robinson Why Nations Fail?, 245-273.

${ }^{14}$ Dietmar Rethermed, The Routledge Companion to Decolonization (New York: Routledge, 2006), 1-4.

15 World Bank, "Export processing zones," Policy and Research Series Paper 20. (Washington, D.C.: The World Bank, 1992).

${ }^{16}$ Arpita Mukherjee, et al., Special Economic Zones in India: Issues, Status and Potential (Singapore: Springer Nature, 2016), 2.
} 
[T] he development of free trade zones got a significant boost in the 1960s and 1970s because growing international specialization, global production relocation by transnational corporations and an increasing orientation by host countries towards exports necessitated the development of special economic zones. In this respect, one of the most startling success stories of SEZs comes from China. The country adopted the free zone policy later than India and it only embraced the concept of SEZs in the late 1970s. The first wave of SEZs was established in China in 1980. Since then, SEZs have become a spectacular success and have emerged as a major driver of growth and exports in China. ${ }^{17}$

As the preceding indicate, China has, in the last forty years, emerged as the world's second largest economy. Importantly, it has lifted around 800 million people from abject poverty since 1979 as a result of its "reform and opening up" policy which underscored the importance of special industrial zones, particularly in the Shenzhen region, ${ }^{18}$ to realize industrial growth. ${ }^{19}$ Besides India and China, in Asia quite a number of developing countries such as Bangladesh-with currently high GDP growth rate after India in South Asia ${ }^{20}$ - the ASEAN nations and other "emerging countries" are accruing economic dividends from effective operationalization of SEZs. ${ }^{21}$ In addition, Russia, in recent times, has also ventured in industrial "clusters" to diversify its industrial production and alleviate regional economic disparity in the wake of the 2008 global financial crisis. ${ }^{22}$ The SEZs are also a fact of economic life in most of the Latin American countries. The following highlights it categorically:

The LA [Latin American] industrial park movement began in Brazil, Mexico, and the Dominican Republic in the 1960s and progressed throughout the remaining countries in the subsequent decades. A similar pattern was evident for technology intensive, science and research parks that began to emerge during the 1980s and 1990s and greatly proliferated throughout the 2000s. Despite the scale of interest in technology parks across Latin America, Brazil and Mexico, the two largest economies in the region, are leading in their implementation of parks. $^{23}$

\footnotetext{
17 Ibid.

18 Malini L. Tantri, “Trajectories of China's Integration with the World Economy through SEZs: A Study of Shenzhen SEZ," China Report 49, no. 2 (2013): 227-250.

19 Graham Allison, "Beijing's anti-poverty drive has lessons for all," The Telegraphy, 28 August 2018. https://www.telegraph.co.uk/china-watch/society/decreasing-chinas-poverty/ (accessed on 7 May 2019).

20 Nazmul Ahasan, "Bangladesh to become world 3rd fastest growing economy in world in 2019," Dhaka Tribune, 22 January 2019. https:/www.dhakatribune.com/business/2019/01/22/bangladesh-tobecome-3rd-fastest-growing-economy-in-world-in-2019 (accessed on 3 May 2019).

21 Susanne A. Frick, et al., "Toward Economically Dynamic Special Economic Zones in Emerging Countries," Economic Geography. https://doi.org/10.1080/00130095.2018.1467732 (accessed on 2 May 2019).

22 Nataliya Klimova, et al., Innovation in Clusters: Understanding Universities, Special Economic Zones, and Modeling (Switzerland: Springer Nature, 2016), 45-87.

23 Andrés Rodríguez-Pose Daniel Hardy, Technology and Industrial Parks in Emerging Countries: Panacea or Pipedream? (London: Springer Mature, 2014), 31-45.
} 
Last but not least, the African countries-in order to achieve economic growth through promotion of their exports-are also engaged, in certain cases with the Chinese collaboration, in the construction of special economic zones. ${ }^{24}$ The popularity of SEZs has, thus, increased in last two decades. For example, there were around 176 SEZs in 47 countries in 1986, whereas, as per the International Labor Office's estimation in 2006 , the number stood at 35,00 in 130 countries in $2006 .{ }^{25}$ In addition, based on various studies, the Word Bank, in 2017, put the number of SEZs approximately at 43,00 , globally. ${ }^{26}$ According to a study published, in 2019 , by the United Nations Conference on Trade and Development (UNCTAD) "there are nearly 5400 SEZs today, more than 1000 of which were established in the last five years. At least 500 more zones (approximately 10 per cent of the current total) have been announced and are expected to open in the coming years." 27

As far as Pakistan is concerned, in the pre-CPEC period (pre-2013), it had already experimented in export processing zones and, importantly, the country hosted certain number of SEZs at various locations. This is further discussed in the following section.

\section{Pakistan's Past Experimentation with SEZs}

Historically, almost every district of Pakistan had an SEZ with proper infrastructure and various incentives for local and international investors (see Table 1). For example, Punjab, the population-wise largest province, hosts around twenty SEZs, whereas Sindh, Balochistan and Khyber-Pakhtunkhwa (KP) carry thirty, seven and twelve SEZs, respectively. Out of the above-mentioned, certain such zones were successful in terms of established industry and generation of employment and capital; there are failed cases, too. The failure of such industrial parks can be ascribed to their remoteness from the major urban and industrial areas. For example, the Rashakai Economic Zone is located some $70 \mathrm{~km}$ away from Peshawar-which is the provincial capital of KP and major urban hub from a commercial perspective. Similarly, Khairpur Economic Zone is established some $30 \mathrm{~km}$ away from Khairpur city.

Moreover, certain major cities of Pakistan also host certain industrial clusters (small industrial units which are not part of an SEZ) because of their added strength in skilled workforce, availability of raw material, supporting institutions and strong

\footnotetext{
${ }^{24}$ Thomas Farole and Gokhan Akinci, ed., Special Economic Zones: Progress, Emerging Challenges, and Future Directions (Washington: The World Bank, 2011), 69-96.

25 Jean-Pierre Singa Boyenge, "ILO database on export processing zones (Revised)," (Geneva: International Labor Organization (2007). http://www.ilo.org/public/libdoc/ilo/2007/107B09_80_engl.pdf (accessed on 6 May 2019).

26 The World Bank, "Special Economic Zones: An Operational Review of Their Impacts," (Washington, D.C.: The World Bank, 2017), 9.

27 "Special Economic Zones," United Nations Conference on Trade and Development (UNCTAD), 2019. https://unctad.org/en/PublicationChapters/WIR2019_CH4.pdf (accessed on 15 July 2020).
} 
historical linkages with the local and global supply chains. For instance, such clusters include sports and surgical clusters in Sialkot, textiles cluster in Faisalabad, fan cluster in Gujarat and engineering cluster in Gujranwala-all these cities are located at considerable distance in Punjab. In addition, there are certain industrial parks (specialized industrial units which formally are not part of an SEZ) in Pakistan which include Rachna Industrial Park (Lahore), Marble City (Lahore) and Textile City (Port Qasim, Karachi). The distance between Lahore and Karachi is around $1200 \mathrm{~km}$. Some of the newly established industrial estates consist of Value Addition City (Sheikhupura-Faisalabad Expressway), M-3 Industrial City (Faisalabad) and Quaid-i-Azam Apparel Park (M-2 Lahore). ${ }^{28}$

\section{Proposed Special Economic Zones under CPEC}

China and Pakistan signed the Memorandum of Understanding (MoU) in 2013 that served as the cornerstone of the China-Pakistan Economic Corridor. The 2015 visit of Pakistan by the Chinese President Xi Jinping formalized CPEC in terms of allocation of 46 billion US\$. ${ }^{29}$ By the end of 2017, the sum total of loans and investment under CPEC has crossed 60 billion US\$. Significantly, the early harvest projects under CPEC have already been operationalized and scores of projects in port, energy, railways, roads, etc., are currently underway. ${ }^{30}$

To consolidate CPEC and enhance bilateral economic cooperation, the Chinese and Pakistani governments concluded, in the sixth Joint Cooperation Committee (JCC) held in December 2016, to establish Special Economic Zones. ${ }^{31}$ The total number of such SEZs varied from initially over hundred to gradually reduced to forty-six. ${ }^{32}$ However, later, the Pakistani authorities, in particular, the Ministry of Planning, Development \& Reform and the Board of Investment (that works under the Prime Minister Secretariat) proposed the construction of nine industrial zones in different parts of Pakistan. Its outline is given in Table 2.

As the table above suggests, the Special Economic Zones are considered the main pillars of China-Pakistan Economic Corridor as well as the economic growth of the two countries. To speed up the construction process of the proposed SEZs, initially four prioritized zones under CPEC were short-listed for bilateral industrial cooperation: ICT Model Industrial Zone (Islamabad), Allama Iqbal Industrial City (Punjab),

\footnotetext{
28 Mahmood, "Opportunities and Challenges of Sino-Pak Industrial Cooperation and Industrial Zones Construction".

29 Ejaz Hussain, "China-Pakistan Economic Corridor: Will It Sustain Itself?," Fudan Journal of the Humanities and Social Sciences 10, no. 2 (2017): 145-59.

${ }^{30}$ Liang Tong, "Cpec Industrial Zones and China-Pakistan Capacity Cooperation," Strategic Studies 35 (2015): 174-184.

31 “6th JCC on CPEC held in Beijing," China Daily, 30 December 2016. http://www.chinadaily.com.cn/ world/2016-12/30/content_27820740.htm (accessed on 22 April 2019).

32 Iftikhar Ahmad and Zhou Taidong, "Special Economic Zones in Pakistan: Promises and Perils," Pakistan Institute of Development Economics (PIDE), Islamabad, 2020. https://www.pide.org.pk/Research/ Research-Report-Special-Economic-Zones-in-Pakistan-Promises-and-Perils.pdf (accessed on 15 July 2020).
} 
Table 1 Existing SEZs in Pakistan

\begin{tabular}{lll}
\hline No. & Type & Location \\
\hline 1 & Karachi Export Processing Zone & Karachi (Sindh) \\
2 & Risalpur Export Processing Zone & Risalpur (KP) \\
3 & Sialkot Export Processing Zone & Sialkot (Punjab) \\
4 & Gujranwala Export Processing Zone & Gujranwala (Punjab) \\
5 & Khairpur Special Economic Zone & Khairpur (Sindh) \\
6 & Rashkai Economic Zone & Rashakai (KP) \\
7 & Gadoon Economic Zone & Swabi (KP) \\
8 & Hattar Economic Zone & Haripur (KP) \\
\hline
\end{tabular}

Data gathered by the author from multiple sources

Rashakai Economic Zone (KP) and Dhabeji (Sindh). ${ }^{33}$ Most recently, however, Pakistan's Prime Minister Imran Khan-during the course of participation in China's Second Belt \& Road Forum (BRF) of the BRI-has signed various agreements with his Chinese counterparts. Importantly, one of the agreements was related to the construction of Rashakai Economic Zone as a topmost priority. ${ }^{34}$ Importantly, as per official updates, groundbreaking of Rashakai Economic Zone is expected in 2020 . $^{35}$ The feasibility work on remaining SEZs is underway in accordance with the second phase of CPEC. ${ }^{36}$ The proposed SEZs offer multiple opportunities to both the Chinese and Pakistani government, firms and people. The following section of the article discusses it in detail.

\section{Opportunities Offered}

Pakistan requires a developed industrial sector to lay a solid foundation for its economic recovery and revival; the Special Economic Zones are supposed to provide a wide range of opportunities to sustain enhanced industrialization. Through industrial zone production and export hubs of high-quality manufactured goods, Pakistan

\footnotetext{
33 Parvez Jabri, "Special Economic Zone to establish on priority: BOI," Business Recorder, 25 February 2019. https://www.brecorder.com/2019/02/25/476936/special-economic-zone-to-establish-on-prior ity-boi/ (accessed on 22 April 2019).

${ }^{34}$ CPEC, "Various agreements signed as PM Imran concludes his visit to China," China-Pakistan Economic Corridor (Islamabad: Ministry of Planning, Development and Reform, 2019). http://www. cpecinfo.com/news/various-agreements-signed-as-pm-imran-concludes-his-visit-to-china/ $\mathrm{NzAyNg}==$ (accessed on 8 May 2019).

35 “Rashakai Economic Zone, M-1, Nowshera," CPEC Authority, Islamabad, 2020. http://cpec.gov.pk/ introduction/1 (accessed on 16 July 2020).

36 "Special Economic Zones to be built in second phase of CPEC," Express Tribune, 6 January 2020. https://tribune.com.pk/story/2130974/1-special-economic-zones-built-second-phase-cpec/ (accessed on 12 February 2020); see also "CPEC Projects Progress Update," CPEC Authority, Islamabad, 2020. http:// cpec.gov.pk/progress-update (accessed on 16 July 2020).
} 
Table 2 Proposed SEZs under CPEC

\begin{tabular}{lll}
\hline No. & Type & Location \\
\hline 1 & Rashakai Economic Zone & Nowshera (KP) \\
2 & China Special Economic Zone & Dhabeji (Sindh) \\
3 & Bostan Industrial Zone & Quetta (Balochistan) \\
4 & Allama Iqbal Industrial City & Faisalabad (Punjab) \\
5 & ICT Model Industrial Zone & Islamabad \\
6 & Industrial Park on Pakistan Steel Mills Land & Port Qasim (Federal Government) \\
7 & Special Economic Zone & Mirpur (Azad Kashmir) \\
8 & Mohmand Marble City & Mohmand Agency (ex-FATA) \\
9 & Moqpondass Special Economic Zone & Gilgit-Baltistan (Northern Areas) \\
\hline
\end{tabular}

Government of Pakistan, "CPEC Special Economic Zones (SEZs)," (Islamabad: Ministry of Planning, Development \& Reform, 2018). http://cpec.gov.pk/special-economic-zones-projects (accessed on January 9,2018$)$

is likely to be favorably positioned in the regional and international market. Whereas CPEC is expected to enhance investment and infrastructure in Pakistan and the western part of China, the construction and optimization of the proposed SEZs are likely to boost up industrial growth and economic activity not only within Pakistan but also between China and Pakistan. The following opportunities are expected to come with the establishment of the SEZs.

To begin with, the proposed Special Economic Zones are expected to work as a strong economic incentive for Pakistani authorities to introduce reforms in order to improve upon domestic business environment, governing behavior, productive capacity, export base and enhance commercial attractiveness for further foreign investments. Furthermore, industrialization with a new face is likely to create jobs for the country's large but underemployed population. The intended industrial activity under SEZs in general and CPEC in particular would expectedly generate employment for the growing educated workforce. In addition, capacity-building efforts through vocational and technical training would also help local workforce to catch up in quality skills. ${ }^{37}$

Secondly, the SEZs offer an opportunity to attract Pakistani diaspora with their skills and knowledge along with their accumulated capital for more profitable prospects in the country. The SEZs can enable firms to agglomerate and get benefits of external economies and will thus provide opportunity to put domestic industries on a higher path of the learning curve. Thirdly, trade generation opportunities are likely to induce both the states improve and strengthen bilateral trade regime. Moreover, within SEZs, Pakistani companies either competing or complementing Chinese companies would learn latest business and trade techniques from their Chinese

\footnotetext{
37 Muhammad Ali Saeed, "Growth of Services Sector in Pakistan: Opportunities for the Private Sector" (paper presented at the International Academic Seminar on Industrial Cooperation and Construction of Industrial Zones, CPEC, Peking University, Beijing, 2018).
} 
counterparts. In addition, the global firms that are overwhelmingly organizing their production and trade in increasingly complex global value and supply chains - and are, thus, looking for the least costly locations-Special Economic Zones can provide a platform to reap the benefits of such opportunities that are literally ignored by the Pakistani authorities. ${ }^{38}$

Fourthly, the agreed upon SEZs offer an opportunity to strengthen technology cooperation between Chinese and Pakistani companies. Moreover, the SEZs provide with opportunity to manage labor pooling, thus cutting down search cost and reducing unemployment of skilled labor. Besides, while working within a SEZ, there could be a strong possibility of nourishing innovative ideas that can be disseminated across companies and corporations. Lastly, the proposed SEZs, which would be operationalized in the second phase of China-Pakistan Economic Corridor (2020-2025), carry the potential to establish linkages with the huge Chinese market; and the Chinese SEZs, in this respect, may create a strong and sustainable business integration through trade and investment. Nonetheless, these potential set of opportunities is prone to multiple challenges which are indicated in the following section.

\section{Challenges}

Indubitably, China-Pakistan Economic Corridor is a well-thought-out long-term project aiming at bilateral trade and commercial cooperation. ${ }^{39}$ Though the CPEC is at its initial phase, some of its early harvest projects have already been completed and the second phase kick-started in $2020 .{ }^{40}$ However, there are voices from within, if not outside, Pakistan that approached the Corridor extremely critically. Regardless, the Pakistani government held its ground and the project is now entering into its next phase where Special Economic Zones are supposed to act as an economic pillar of CPEC. However, the construction and function of the SEZs are likely to face a set of challenges, which are categorized, in the following, as structural, political and security challenges.

\subsection{Structural Challenges}

One of the major structural challenges pertains to the location of a Special Economic Zone. As will be discussed in the next section, politics, at all level, does influence public policy in Pakistan. Therefore, each of the four provincial governments, the local and provincial political parties and regional stakeholders differ over the

\footnotetext{
38 "Pakistan, China jointly working for establishment of special economic zones," The Nation, 7 January, 2018. https://nation.com.pk/07-Jan-2018/pakistan-china-jointly-working-for-establishment-of-speci al-industrial-zones (accessed on 23 April 2019).

39 Government of Pakistan, "Long Term Plan for China-Pakistan Economic Corridor (2017-2030)," (Islamabad: Ministry of Planning, Development and Reform, 2017). http://cpec.gov.pk/brain/public/ uploads/documents/CPEC-LTP.pdf (accessed on 23 April 2019).

40 CPEC, "CPEC Projects progress Update," (Islamabad: Ministry of Planning, Development and Reform, 2019). http://cpec.gov.pk/progress-update (accessed 23 April 2019).
} 
site of a SEZ and present(ed) a respective province and/or region such as Gilgit-Baltistan as a perfect natural location-which might not be the case in pure economic terms. Moreover, Pakistan's human resources are not attuned to the proposed SEZ requirements. Neither they are proficient enough to operate Chinese technological tools and machines. This will be a major challenge for the government to fully benefit from employment opportunity offered by the SEZs. ${ }^{41}$

Access to finance could be termed as equally important impediment for the growth of industries. Such a problem doubles in magnitude with reduction in size of a firm. Pakistani governmental bodies generally lack experience and knowledge in SEZs management, i.e., doing business with foreign investors. It may seriously hinder the implementation capacity of the government institutions. Therefore, the challenge posed is to develop requisite capacity of public sector institutions.

Furthermore, the creation of environment for fast and effective dissemination of technology is necessary. Ensuring adequate number and size of allied and supplier firms and locating them in SEZs to draw benefits of external economies will be a major challenge, too. Similarly, local connectivity, inter-zonal liaison and provision of utilities would be a structural impediment to be taken care of. Besides, the incidence of financial corruption is a serious challenge in so far as transparency of various CPEC projects is concerned. ${ }^{42}$

By and large, structural challenges point to consistency in economic policies, avoidance of sudden policy reversal, transparency in decision-making, eradication of corruption and expansion of financial markets to provide enough finance to industries, availability of qualified manpower through vocational training and conducive business environment including effective property rights protection and fair and speedy dispute resolution mechanism. ${ }^{43}$

\subsection{Political Challenges}

One of the main political challenges relates to due share in CPEC and the SEZs on the behalf of provincial governments, regional and local stakeholders. In 2015, when the Chinese President Xi Jinping formally launched CPEC, the Khyber-Pakhtunkhwa and Balochistan government and the regional political parties differed, for example, over "CPEC routes." The so-called route controversy ${ }^{44}$ was blamed on the Punjab (and the federal) government which were held partisan by the opposition political parties such as Pakistan Tehreek-e-Insaf (PTI) and Pakistan People's Party (PPP). Importantly, political parties based in non-Punjab provinces, especially Balochistan that hosts Gwadar Port, raised questions on the feasibility, outreach,

\footnotetext{
${ }^{41}$ Lu Shulin, "Significance and Relevant Issues of Industrial Zones Construction under Cpec" (paper presented at the International Academic Seminar on Industrial Cooperation and Construction of Industrial Zones, CPEC, Peking University, Beijing, 2018).

42 “CPEC transparency,” Dawn, 17 March 2019. https://www.dawn.com/news/1470126 (accessed on 12 February 2020).

43 Mahmood, "Opportunities and Challenges of Sino-Pak Industrial Cooperation and Industrial Zones Construction".

44 Ejaz Hussain, "China-Pakistan Economic Corridor: Will It Sustain Itself?,".
} 
functions and strategic implications of the China-Pakistan Economic Corridor. In a similar vein, local politicians and rights activists from, for example, Gilgit-Baltistan highlighted the potential risk for physical environment owing to CPEC traffic chains. ${ }^{45}$

In order to address the grievances of the smaller provinces, the Federal Government of Pakistan led by Pakistan Muslim League-Nawaz (PML-N) held a series of meetings with key leaders of provincial governments, regional dispensation and proclimate change associations. Particularly, the Sharif Government (2013-2017) ${ }^{46}$ was able to organized All Parties Conference on CPEC more than twice. Consequently, the mainstream and regional political parties and groups in general and the federal and provincial governments in particular achieved consensus on the nature and character of China-Pakistan Economic Corridor. Thus, the "route controversy" was amicably resolved with due share of roads and railways provided to different provinces and regions. ${ }^{47}$

The foregoing, however, did not result into silencing the debate over CPEC. Little wonder, Senator Mir Hasil Bizenjo, ${ }^{48}$ who was Federal Minister for Ports and Shipping, argued on the floor of the country's Senate that "91 per cent of the revenues to be generated from the Gwadar port as part of the China-Pakistan Economic Corridor (CPEC) would go to China, while the Gwadar Port Authority would get 9pc share in the income for the next 40 years." ${ }^{49}$ In addition, the CPEC Long Term Plan (LTP) has invited concerns and questions from stakeholders and analysts alike. By and large, the political elite and public at large from smaller provinces demanded more transparency and fair play in terms of detailing publicly the pros and cons of different agreements reached between Chinese and Pakistani authorities. Indeed, the current Pakistan Tehreek Insaf (PTI) government led by Prime Minister Imran khan initially viewed certain CPEC projects skeptically. ${ }^{50}$

This means that though CPEC has been successful in terms of acceptability as a mega economic project between China and Pakistan, it still requires further fine-tuning at the popular level. ${ }^{51}$ If one goes by the foregoing, it is speculated that the construction of the Special Economic Zones would not be free of political challenges emanating

\footnotetext{
45 Lan Jiang, "Impact of Local Politics on Cpec: Research Focusing on Several Energy Programs" (paper presented at the International Academic Seminar on Industrial Cooperation and Construction of Industrial Zones, CPEC, Peking University, Beijing, 2018).

${ }^{46}$ Nawaz Sharif was disqualified by the county's Supreme Court on 28 July 2017. The term Sharif Government refers to the period during which he served as Pakistan's prime minister (July 2013 to July 2017).

${ }^{47}$ Ahmad Noorani, “CPEC route controversy routed," January 16, 2016. https://www.thenews.com.pk/ print/90708-CPEC-route-controversy-routed (accessed on 2 January 2019).

${ }^{48}$ Mir Hasil Bizenjo was the president of National Party (NP) that is nationalist in nature.

49 Iftikhar A. Khan, "China to get 91pc Gwadar income, minister tells Senate," November 25, 2017.https ://www.dawn.com/news/1372695 (accessed on 5 January 2019).

${ }^{50}$ Ejaz Hussain, "Will change in government affect China-Pakistan Economic Corridor? The BRI, CPEC and the Khan Government: An analysis," Chinese Journal of International Review. https://doi. org/10.1142/S2630531319500045 (accessed on 12 October 2019).

${ }^{51}$ Amjad Ali Shah, “CPEC projects: KP demands 'rightful' share," January 3, 2016. https://fp.brecorder. com/2016/01/201601031430/ (accessed on 13 April 2019).
} 
primarily from non-Punjab provinces and autonomous regions. Already there has been considerable debate registered on the location, size and number of Special Economic Zones by the KP and Balochistan, if not Sindh, based nationalist political parties such as Pakhtunkhwa Milli Awami Party (PkMAP), Awami National Party (ANP) and the National Party (NP). Little wonder, in initial meetings between the federal and provincial government, the number of SEZs was reduced from hundred plus to forty-six whereby each government strove to host maximum number of SEZs in order to uplift a respective province from poverty, economic slowdown and unemployment. ${ }^{52}$

However, further negotiations among the regional, provincial and federal stakeholders brought the proposed number of SEZs down to nine whereby each province, Islamabad Capital Territory (ICT), and region host one each. Apparently, this seems a fair start in terms of equitable distribution numerically; however, issues and concerns regarding the size (the largest size SEZ is proposed for Punjab) and economic competitiveness, industrial base of a province/region and overall economic indicators of an area may pop up in the following years if not months. As per the political culture of Pakistan, political parties and politicians, at all level, see to their petty interest and that too at the expense of national interest. Thus, it is very likely that SEZs are further highlighted on partisan lines where each stakeholder tends to get the lion's share. Political disagreements and tussles, thus, amount to serious political challenges that demand serious and steady debate, negotiations and conflict resolution mechanism.

\subsection{Security Challenges}

Pakistan is facing serious threats in the form of religious extremism and terrorism. Modern terrorism that Pakistani society and state is suffering from is essentially post-9/11. When the Pakistani military regime led by General Pervez Musharraf (1999-2007) decided to support the USA-led War on Terror against the Taliban and Al-Qaeda, the latter, in reaction, took on Pakistan by invoking (suicide) terrorism as a strategic weapon. Consequently, around thirty thousand Pakistanis, both civil and law enforcement, have lost their lives in multiple incidences of terrorism from 2003 till 2019. Though the number of civilian and security personnel fatalities has comparatively gone down since 2014 due largely to the various military operations, the phenomenon of terrorism has yet not been wiped out completely. For example, during 2013-2019, 6528 civilians and 2312 security personal lost their lives in (suicide) terrorism. ${ }^{53}$ In addition, by August 21, 2020, 28 civilians and 125 security personnel lost their lives in 112 incidences of terrorism in Pakistan. ${ }^{54}$

Given opportunity, a terrorist organization such as Tehreek Taliban Pakistan (TTP) and/or Jamaat-ul-Ahrar (JuA) strikes mostly on the country's minorities, i.e., Christians, in mostly far flung areas such as Quetta; the latter witnessed, on April

\footnotetext{
52 “Government to set up 46 SEZs along CPEC route," Express Tribune, July 20, 2017. https://tribu ne.com.pk/story/1461888/govt-set-46-sezs-along-cpec-route/ (accessed on 15 March 2019).

53 South Asia Terrorism Portal, "Datasheet-Pakistan: Yearly Fatalities,".https://www.satp.org/datasheetterrorist-attack/fatalities/pakistan (accessed on 12 February 2020).

54 Ibid.
} 
12, 2019, another deadly terror attack on its Hazara minority that lost 20 lives, whereas 48 people were injured. ${ }^{55}$ Here, it is pertinent to mention that a Chinese couple was initially kidnaped and ultimately killed in Quetta in 2017 by a terrorist organization. ${ }^{56}$ Moreover, the Chinese consulate in Karachi was attacked by terrorists belonging to Balochistan Liberation Army (BLA); the attack was foiled by Pakistani security forces with the loss of two policemen. ${ }^{57}$

Anti-Pakistan terrorist networks work in tandem with regional proxies and powers such as India whose intelligence operator, Kulbhushan Jadhav, was arrested near Iran-Pakistan border by Pakistan's security forces. ${ }^{58}$ It is no secret that the current Indian Prime Minister, Narendra Modi, had talked publicly against China-Pakistan Economic Corridor. ${ }^{59}$ In the context of domestic and regional security threats to its sovereignty, in general, and CPEC, in particular, the Pakistan state has taken due measures that include pooling up a special armed force, ${ }^{60}$ consisting of military and the civil law enforcement institutions, for the protection of CPEC projects and personnel.

Thus, China-Pakistan Economic Corridor has, so far, survived major terrorist attack on its infrastructure, equipment and workforce. However, potential security threats ought not to be ignored. This then raises security concerns for second phase of CPEC whereby Special Economic Zones are accorded top priory by the Chinese and Pakistani government. Will the local, provincial or federal government provide security to the SEZs at, for example, different stages of construction? If it is a joint venture of, for instance, provincial and federal government, which government will call the shots? Who will bear the financial and logistical cost? If it is the sole responsibility of the provincial government, will a province be able to manage a SEZ's security on its own? Overall, will the Chinese companies and workforce be satisfied with the security arrangements provided by the Pakistani authorities? The foregoing has, thus, highlighted major security challenges to the SEZs, in particular, and, CPEC, in general. The next section of the paper attempts to provide a set of strategies vis-à-vis the posed challenges whose solutions will ensure the safety of not only the Special Economic Zones but also that of Pakistan's society and economy.

\footnotetext{
55 Syed Ali Shah, "20 killed, 48 injured in attack targeting Hazara community in Quetta," Dawn, 12 April 2019. https://www.dawn.com/news/1475621 (accessed on 20 April 2019).

56 Naveed Siddiqui, "Islamabad confirms death of Chinese couple abducted from Quetta," Dawn, 30 October 2017. https://www.dawn.com/news/1367264 (accessed on 23 April 2019).

57 Imtiaz Ali and Asim Khan, "Terror attack on Chinese Consulate foiled; 3 terrorists killed," Dawn, 23 November 2018. https://www.dawn.com/news/1447192 (accessed on 13 October 2019)..

58 "Who is Kulbhushan Jadhav?," Dawn, 10 April 2017. https://www.dawn.com/news/1326117 (accessed on 21 April 2019).

59 "PM Modi raises India's concern over CPEC which runs through PoK," Indian Express, September 4, 2016. http://indianexpress.com/article/india/india-news-india/prime-minister-narendra-modi-raises-india s-concern-over-cpec-which-runs-through-pok-3013260/ (accessed on 25 December 2018).

60 Ejaz Hussain, "Cpec: Governance and Security Challenges-Implications for the Belt and Road Initiative," Chinese Political Science Review 4, no. 1 (2019): 135-47.
} 


\section{Strategies}

The following are certain strategies to tackle structural, political and security challenges. These strategies, it is posited, can deliver tangible results if implemented in letter and spirit.

\subsection{Solutions for Structural Challenges}

Pakistan has to take a number of steps in close collaboration with China to transform the highlighted challenges into capabilities. As far as structural challenges are concerned, the fundamental principle that Pakistani government ought to abide by is the economic competitiveness of the area where a Special Economic Zone is proposed. It is important that during consultation on site selection, all the concerned stakeholders be on board. Second, the Pakistani authorities need to initiate policies in coordination with Pakistani and Chinese companies. The Pakistani firms should learn from the Chinese experiences for effective policy implementation. In this respect, it is advisable to implement the Special Economize Zone Act 2012 (revised) that was promulgated before the launch of CPEC so that economic aspirations of both the Chinese and Pakistani investors are realized. Moreover, to train the SEZoriented workforce, it is pertinent to establish modern vocational and technology institutions while taking inference from the Chinese vocational education and technology know-how since they are comparatively state of the art in terms of innovation and dissemination of skills. ${ }^{61}$

In order to make SEZs an effective strategy and specimen for industrial growth, its financial side cannot be ignored. In this respect, the Pakistani and Chinese governments ought to work in tandem to devise a policy to provide adequate funds to small- to medium-size firms that lack indigenous financially stability. Nevertheless, such financials should be firm-friendly to attract further investment nationally and (extra-)regionally. Here, the role of Pakistani diaspora could be very handy since they deposit, on average, around 10 billion US\$ in remittances per annum. ${ }^{62}$

Furthermore, it is essential for Pakistani and Chinese authorities to make Special Economic Zones a part of global supply chain and global value chain by increasing the competitiveness of supplier firms with improved reliability and efficiency. This can be achieved by introducing business supporting policies, modernizing trade facilitation system and infrastructure, devising a special cadre of customs officials and staff, cutting on delays, bureaucratic hurdles and, importantly, eradication of financial corruption. In addition, there is a need to promote SEZs as enclaves of good practices and self-containment, supported by sound infrastructure and service provider firms. Ideally, the Pakistani government should engage a private firm to develop and manage the SEZs, while the government should be an active player in

\footnotetext{
${ }^{61}$ Mahmood, "Opportunities and Challenges of Sino-Pak Industrial Cooperation and Industrial Zones Construction".

62 Waheed Abbas, "Overseas Pakistani remit 10\% more funds in first half of 2018-2019, Khaleej Times, 17 January 2019. https://www.khaleejtimes.com/business/economy/remittances-lifeline-to-pakistanseconomy (accessed on 23 April 2019).
} 
provision of transport, electricity, water, telecommunications, waste disposal and other infrastructures to link SEZs with global and local supply chains. ${ }^{63}$

Besides, the Pakistani government ought to accord complete and secured property rights protection to ensure sustainability and attract Chinese firms. In this respect, market access is to be ensured through efficient transportation system. ${ }^{64}$ Such measures will help improve transportation of much needed raw materials and finished goods. Last but not least, Pakistan ought to negotiate with Chinese government to secure duty-free status to exports originating from the SEZs. To realize it, Pakistani authorities should promptly conclude special trade agreement for SEZs in addition to the existing bilateral free trade agreement. Since China has already effectively positioned its SEZs to establish linkages with allied and supplier industries, Pakistan should act fast to capitalize on the Chinese experiences. In this respect, it is suggestive to create complementarity between Pakistani and Chinese SEZs for mutual advantage and connectivity.

\subsection{Solutions for Political Challenges}

As discussed earlier in the paper, politics affects policy and in the Pakistani case, it did affect (economic) policies for the country's history is replete with cases where long-term economic plans suffered from political instability. ${ }^{65}$ Therefore, to make CPEC a success story, Pakistani politicians and political parties have their work cut out. In this respect, it is urgently required on the part of the federal government to engage regional and nationalist political parties in debate and discussion on the pros and cons of CPEC in general and SEZs, in particular. Perhaps there is no harm in gradually increasing the equitable number and size of industrial zones in different parts of Pakistan. Such a policy measure will help generate political confidence and economic collaboration among the four provinces, regions and the federal government. More SEZs mean more local and regional participation in CPEC and economic growth and social progress of the country. Moreover, the expansion of further SEZs in close partnership with local and provincial authorities is likely to assuage local and regional socioeconomic grievances by engaging local skilled manpower of, for example, Gilgit-Baltistan and Balochistan in the SEZs in particular and CPEC in general. ${ }^{66}$

To realize the foregoing, it is suggested that the federal government does not ignore local and regional political aspirations. Importantly, the mainstream political parties, which are major stakeholders of CPEC, ought not to sideline nationalist political parties of KP, Sindh and Balochistan. Thus, there is need of developing

\footnotetext{
63 Mahmood, "Opportunities and Challenges of Sino-Pak Industrial Cooperation and Industrial Zones Construction".

64 Ibid.

65 Ejaz Hussain, Military Agency, Politics, and the State in Pakistan (New Delhi: Samskriti, 2013), 15056.

66 Saeed Shafqat, "China's Rise: How Is It Impacting the Gulf, Iran, Pakistan and beyond," Asian Journal of Middle Eastern and Islamic Studies, 11, no. 1 (2017): 32.
} 
an effective mechanism for inter-parties coordination and policy formulation. At the moment, the federal government conducts All Parties Conference (APC) to discuss serious policy issues of national magnitude. This, in my view, is a ad hoc measure. A long-term institutional solution lays in the establishment of a permanent interparties coordination body responsible for holding meetings, generating consensus on policy issues and, overall, ensuring participation and policy role of smaller political parties.

\subsection{Solutions for Security Challenges}

As already discussed in the preceding sections, Pakistan is mired in multiple problems of which bad governance and insecurity are quite alarming for without orderly rule; it is impossible to achieve economic growth and societal development. Since CPEC is a joint venture, it is equally essential to ensure safety of the (non-) CPEC workforce and logistics along with heavily invested Corridor infrastructure.

To begin with, China-Pakistan relations have achieved "a factor of durability". ${ }^{67}$ What this implies in strategic and military terms is that both the countries amicably resolved potential areas of conflict, i.e., broader management, and, importantly, consolidated bilateral relations since the mid-1960s. Consequently, since 2015, China-Pakistan relations have taken a new turn where geoeconomics is predicated on geopolitics in terms of formalization of CPEC. A considerable section of the Chinese workforce is engaged in Gwadar, Balochistan, where more than fifty major projects in infrastructure and energy are underway. ${ }^{68}$ The Pakistani authorities, being aware of restive security situation particularly in Balochistan and generally in the rest of the country, established a security regime to safeguard the Chinese labor from mostly internal threats. ${ }^{69}$ In October 2019, the Special Security Division (SSD) has been expanded in terms of establishment of its "southern" command that would exclusively ensure safety of the Chinese executives and workers in Balochistan and Karachi. ${ }^{70}$ Though the kidnapers in Balochistan killed two Chinese nationals in 2017, the overall safety of the Chinese workers has been duly ensured by the government of Pakistan.

Moreover, recently there have been reports of some Chinese nationals having been involved in the so-called marriages scandal; their cases are being invested by the country's law enforcement as per the law. ${ }^{71}$ Nevertheless, the Chinese citizens working in Pakistan have overwhelmingly demonstrated goodwill and good conduct. At the moment, the majority of Pakistanis perceive them friendly people from a friendly country. Nevertheless, given the chaotic security situation in parts of

\footnotetext{
${ }^{67}$ Ghulam Ali, China-Pakistan Relations: A Historical Analysis (Karachi: Oxford University Press, 2017), 190-230.

68 CPEC, "CPEC Projects," (Islamabad: Ministry of Planning, Development and Reform, 2019). http:// cpec.gov.pk/ (accessed on 23 April 2019).

69 Hussain, "Cpec: Governance and Security Challenges-Implications for the Belt and Road Initiative,".

70 Conversation with a senior government official, 9 October, 2019.

71 Neo TV Network, "Iqrar Ul Hassan of Sar E aam Exposed Pak China Marriages,". https://www.youtu be.com/watch?v=ZLFP5oyWnmE (accessed on 13 October 2019).
} 
Pakistan, public safety remains a big challenge for Pakistani law enforcement which, as mentioned above, is taking due measures to enhance security.

In addition, in order to improve CPEC security in general and that of SEZs in particular, Pakistani authorities would have to tackle terrorism on multiple levels. Strategically, Pakistan needs to engage with its neighbors meaningfully. Here, China can play a role by encouraging regional cooperation and peace. Indeed, the quadrilateral Afghan peace process is a step in the right direction. Moreover, China-Iran-Pakistan trilateral engagement carries the potential to devise a collective response to anti-peace elements in the South Asian region. In this respect, the visit, on April 21, 2019, of Pakistani Prime Minister Imran Khan to Iran was very crucial given growing strategic uncertainty in the South Asian region. ${ }^{72}$ Khan paid another visit to Tehran on October 13, 2019, in order to "mediate" between Iran and Saudi Arabia. ${ }^{73}$ If this materializes, it will carry positive implications for CPEC in particular and the Belt and Road Initiative in general.

Importantly, China may also convince the USA - another major stakeholder in the region-to engage Pakistan, Afghanistan and India in a manner that reduces strategic uncertainty. Politically, Pakistani government should strive to negotiate with the locally active extremist and insurgent groups. Ideologically, there is a growing need to conceive and implement a pluralist narrative to counter hate mongers in Pakistani society.

Above all, China and Pakistan would have to play a central role by reinforcing the importance of peace and stability locally, nationally and transregionally. The former must understand the precarious security situation Pakistan is facing where it lost around 30,000 thousand civilians and security personnel in past nineteen years. ${ }^{74}$ Nevertheless, Pakistan must revisit its policies that might have provided an enabling environment to anti-humanity forces. The latter though have been militarily neutralized by the law enforcement of Pakistan, certain militant organizations such as Jamat-ul-Ahrar and TTP, whose captive spokesperson Ehsanullah Ehsan escaped from detention in Pakistan in February 2020, ${ }^{75}$ still pose security challenge. Such organizations are always in search of soft targets to destabilize Pakistani state, society and economy.

Last but not least, for effective CPEC security, Pakistan has to take certain extraordinary measures. On the one hand, there is need to devise a strategy to have local and provincial law enforcement apparatuses, i.e., police, Frontier Constabulary, on board while enhancing policy and operational capacity of civil law

\footnotetext{
72 Sanaullah Khan, "Prime Minister Imran Khan reaches Iran for 2-day official visit," Dawn, 21 April 2019. https://www.dawn.com/news/1477543 (accessed on 23 April 2019).

73 "Pakistan PM Imran Khan leaves for Tehran to mitigate tensions between Iran and Saudi Arabia," India Today, 13 October 2019. https://www.indiatoday.in/world/story/pakistan-imran-khan-leaves-tehra n-mitigate-tensions-between-iran-and-saudi-arabia-1608837-2019-10-13 (accessed on 13 October 2019).

74 South Asia Terrorism Portal, "Fatalities in Terrorist Violence in Pakistan, 2000-2019," 14 April 2019. https://www.satp.org/satporgtp/countries/pakistan/database/casualties.htm (accessed on 22 April 2019).

75 Ihsanullah Tipu Mehsud and Maria Abi-Habib, "Taliban Militant Flees Prison, Claiming Deal With Pakistani Security Forces," The New York Times, 7 February 2020. https://www.nytim es.com/2020/02/07/world/asia/taliban-malala-yousafzai-pakistan.html (accessed on 21 February 2020).
} 
enforcement along with improving human intelligence of strategic locations along CPEC including the Special Economic Zones. On the other hand, the local, provincial and federal governments ought to chalk out a policy framework under which the country's armed law enforcement could work effectively. The recently established CPEC Authority seems a step in the right direction. ${ }^{76}$ Moreover, during the visit of Pakistani civil-military leadership to China in October 2019, the two sides reiterated bilateral commitment to expand CPEC and speed up work on the SEZs. ${ }^{77}$

Lastly, for effective surveillance of SEZs and Gwadar Port, the Chinese government can be helpful in terms of provision of sophisticated gadgets to enhance physical and infrastructural security of the enclave. Within the Gwadar enclave, the Chinese may, in consultation with Pakistani authorities, operate on its own. Nonetheless, handing over of overall security of Gwadar and SEZs to Chinese companies, both public and private, would not be suitable idea and practice given Pakistan's bad experiences with American CIA and Blackwater. ${ }^{78}$ Since 9/11, Pakistanis are overwhelming anti-USA, whereas China's perception at the popular level is, overall, positive. ${ }^{79}$ The Chinese authorities should stay mindful of popular perception.

\section{Conclusion}

China-Pakistan relations are predicated on time-tested strategic confidence. Conventionally, the trajectory of bilateral relations revolved around military strategic realm. Post-9/11, both the countries started exploring new angles to enhance strategic cooperative partnership. With the launch of China's Belt and Road Initiative in 2013, the China-Pakistan Economic Corridor-as a core component of the BRI-was formalized in 2015. The Corridor adds not only economic dimension to bilateral relations but also serves as a catalyst for the consolidation of mutual trust and the realization of economic development of Pakistan whose economy is currently underperforming.

At the core of CPEC lies the concept of Special Economic Zones whose proposed number stands at nine of which, initially, four were selected for early construction. By the end of 2019, the two governments signed various agreements of which one

\footnotetext{
76 Zamir Ahmed Awan, "Pakistan establishes CPEC Authority,". China Daily, 9 October 2019. http:// global.chinadaily.com.cn/a/201910/09/WS5d9d98f4a310cf3e3556f7c5.html (accessed on 14 October 2019).

77 Sanaullah Khan, "Pakistan, China resolve to strengthen strategic partnership as PM Imran concludes visit,”. Dawn, 9 October 2019. https://www.dawn.com/news/1509910/pakistan-china-resolve-to-stren gthen-strategic-partnership-as-pm-imran-concludes-visit (accessed on 14 October 2019).

78 Ejaz Hussain, "China-Pakistan Economic Corridor," (CPEC booklet published by Institute for Research \& Dialog (IRD), International Islamic University, Islamabad, 2018).

79 Tim Craig, "After years of tension, anti-American sentiment ebbs in Pakistan," The Washington Post, 3 May 2015. https://www.washingtonpost.com/world/asia_pacific/after-years-of-tension-anti-americansentiment-ebbs-in-pakistan/2015/05/03/6d0eccfe-dd36-11e4-b6d7-b9bc8acf16f7_story.html (accessed on 13 February 2020).
} 
crucial project was related to the establishment of Rashakai Special Economic Zone on a priority basis. The remaining SEZs would be established and made operational in the ongoing second phase (2020-2025) of China-Pakistan Economic Corridor. Indubitably, Special Economic Zones offer a set of opportunities to both China and Pakistan-ranging from infrastructural development to industrial cooperation. Nonetheless, the SEZs are prone to multiple challenges including security problems. In order to cope with the indicated set of challenges, the article, therefore, provided a set of strategies ranging from political consensus to enhanced security. Finally, the study posits that the SEZs - projected as hallmark of the CPEC under the second phasecarry the potential to be transformed into successful ventures for both the countries and their people if the mentioned measures are taken into policy consideration.

\section{Compliance with Ethical Standards}

Conflict of interests There is no conflict of interests related to authors and/or this article.

Ejaz Hussain did Ph.D. in Political Science from Heidelberg University (2010) and Postdoc from UC Berkeley (2017). He has authored Military Agency, Politics and the State in Pakistan (2013) and coedited Perspectives on Contemporary Pakistan: Governance, Development and Environment (Routledge, 2020). In addition, he has contributed to peer-reviewed journals such as Armed Forces \& Society and Chinese Political Science Review. Dr Hussain has been a visiting fellow at Fudan University. He is DAAD, FDDI and Fulbright fellow. Moreover, he taught at COMSATS University, Islamabad, FC College University, Lahore, and Shanghai International Studies University (SISU), Shanghai, China. Besides, his commentaries have appeared in BBC (Urdu), Express Tribune, The First Post, The Friday Times, Global Times, Daily Times, Naya Daur and CGTN. Currently, he is Associate Professor, Department of Social Sciences, Iqra University, Islamabad.

Muhammad Furqan Rao is presently pursuing $\mathrm{PhD}$ in journalism and communication from the School of Journalism and Communication, Tsinghua University, Beijing, PR China. He received certification in New Media and Communication from Renmin University of China in 2015. Rao has presented papers at UNESCO's conference on Media Information Literacy as well as Conference on Social Media and Journalism Innovations organized by Zhejiang University. Earlier, he worked as journalist with the Associated Press of Pakistan (APP). Moreover, he is fellow of International Centre for Journalists (ICFJ) and Fulbright foundation, USA. 